\title{
Erratum to: Assessing Pro-environmental Behaviour in Relation to the Management of Pollution from Private Sewage Systems
}

Will J. Brownlie • Bryan M. Spears • Sandhya Patidar •

Linda May $\cdot$ Susan Roaf

Published online: 15 March 2015

(C) Springer Science+Business Media New York 2015

Erratum to: Human Ecol 43:131-140

DOI 10.1007/s10745-015-9728-2

In the original version of this article three of the five author names were listed incorrectly as "Will Joseph Brownlie, Bryan Spears, May Linda." The names should be listed as: "Will J. Brownlie, Bryan M. Spears, Linda May." The correct full list of author names is presented above.

The online version of the original article can be found at http://dx.doi.org/ 10.1007/s10745-015-9728-2.

W. J. Brownlie $(\bowtie) \cdot$ B. M. Spears $\cdot$ L. May

Centre of Ecology and Hydrology, Edinburgh EH26 0QB, UK

e-mail: wilown@ceh.ac.uk

S. Patidar $\cdot$ S. Roaf

Heriot Watt University, Riccarton, Edinburgh EH14 4AS, UK 